\title{
New Psychoactive Substance 5-MeO-MiPT In vivo Acute Toxicity and Hystotoxicological Study
}

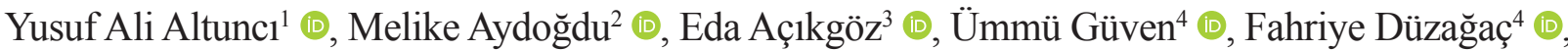 \\ Aslı Atasoy $^{5} \oplus$, Nebile Dağlığlu ${ }^{6}$, Serap Annette Akgür ${ }^{2} \odot$ \\ ${ }^{1}$ Department of Emergency, Ege University School of Medicine, İzmir, Turkey \\ ${ }^{2}$ Department of Addiction Toxicology, Ege University Institute on Drug Abuse, Toxicology and Pharmaceutical Sciences, İzmir, Turkey \\ ${ }^{3}$ Department of Histology and Embryology, Yüzüncü Y1l University School of Medicine, Van, Turkey \\ ${ }^{4}$ Department of Stem Cell, Ege University Health Science Institute, İzmir, Turkey \\ ${ }^{5}$ Department of Forensic Science, Çukurova University, Institute on Addiction and Forensic Science, Adana, Turkey \\ ${ }^{6}$ Department of Forensic Medicine, Çukurova University School of Medicine, Adana, Turkey
}

Background: The hallucinogenic tryptamine analog 5-methoxy-N-methyl-N-isopropyltryptamine (5-MeO-MiPT) causes social problems worldwide. There are several studies on the metabolism; however, not more studies were found in the literature on acute toxicity.

Aims: To report the acute toxicity of 5-MeO-MiPT in mice, followed by quantitative toxicological analysis of blood and organs, hystotoxicological and immunohistochemical analysis of tissues and cells.

Study design: Animal experiment

Methods: In vivo experiments were performed using CD1 adult female mice $(n=26)$. Animals were caged in 4 groups randomly. First group was a control $(n=3)$. Second group was vehicle control $(n=3)$ and injected $150 \mu \mathrm{L}$ of blank solution ( $50 \%$ dimethyl sulfoxide in saline $/ 0.9 \%$ of $\mathrm{NaCl}$ ). While for acute toxicity experiments, 5-MeO-MiPT was added to a blank solution in order to obtain a dose of $0.27 \mathrm{mg} / \mathrm{kg}$ in $150 \mu \mathrm{L}$ injection $(\mathrm{n}=10)$ and the last group were injected $2.7 \mathrm{mg} / \mathrm{kg} 5-\mathrm{MeO}-$ MiPT in a $150 \mu \mathrm{L}$ injection $(\mathrm{n}=10)$. Quantitative toxicological analysis, hystotoxicological and immunohistochemical analysis were performed.

Results: In the toxicological analysis, 5-MeO-MiPT was found negative in biological samples which were control, vehicle control, and $0.27 \mathrm{mg} / \mathrm{kg}$ dose mice groups. 5-MeO-MiPT was found $2.7-13.4 \mathrm{ng} /$ $\mathrm{mL}$ in blood, 11-29 ng/g in kidney, 15.2-108.3 ng/g in liver, and 1.5$40.6 \mathrm{ng} / \mathrm{g}$ in the brain in $2,7 \mathrm{mg} / \mathrm{kg}$ injected group. In a low dose of the 5-MeO-MiPT liver section, compared with normal tissues, the difference in staining was statistically significant $(\mathrm{p}<0.0001)$. In highdose of 5-MeO-MiPT, H-score showed that the increase in the number of Caspase- 3 positive cells was significant compared to the control $(\mathrm{p}<0.05)$. In high-dose of 5-MeO-MiPT, intense Caspase-3 immunoreactivity was observed and the increase in the number of Caspase- 3 positive cells compared to the control was statistically significant $(\mathrm{p}<0.05)$. In brain section, the statistics of the results obtained from the H-score showed that the increase in the number of Caspase- 3 positive cells was significant compared to the control $(\mathrm{p}=0.0183)$. In vehicle control liver section, there were few Caspase- 8 positive cells characterized by a light brown appearance $(\mathrm{p}=0.0117)$. In the high-dose 5-MeO-MiPT group, the numbers of positive cells at low and high doses of 5-MeO-MiPT group were statistically significant compared to the control $(\mathrm{p}<0.05)$. In the high-dose 5-MeO-MiPT group, Caspase-8 immunoreactivity was detected in the glomerular structures. Compared to control, the increase in Caspase-8 immunoreactivity was found to be statistically significant $(\mathrm{p}<0.05)$.

Conclusion: Low-dose 5-MeO-MiPT did not cause any serious histopathological effects on the liver, kidney, and brain. High doses induce apoptotic cell death through caspase activity.
New psychoactive substances (NPS) are new, abusive narcotic or psychotropic substances that can threaten public health and safety (1-3). Because the chemical structure of NPS differs from the stimulating substances, the legislation for these substances is constantly updated $(4,5)$. Products often called "bath salts," "not for human consumption," "legal," "deodorizing," and "plant food," and providing attractive contents of vague descriptions are sold in colorful packaging. In addition, a "health certificate" is marketed on websites showing these are safe and legal (2, 4, 6-8). Between 2008 and 2018, a total of 434 different NPS were reported by East

Address for Correspondence: Yusuf Ali Altunc1, Department of Emergency, Ege University School of Medicine, İzmir, Turkey

e-mail: yusuf.ali.altunci@ege.edu.tr

Received: November 13, $2019 \quad$ Accepted: September 14, 2020 • DOI: 10.4274/balkanmedj.galenos.2020.2019.11.68

Available at www.balkanmedicaljournal.org

ORCID iDs of the authors: Y.A.A. 0000-0002-4803-5419; M.A. 0000-0002-6324-0234; E.A. 0000-0002-6772-3081; Ü.G. 0000-0002-5427-263X; F.D. 0000-0002-4130-2246; A.A. 0000-0001-6901-7511; N.D. 0000-0003-3415-8159; S.A.A. 0000-0001-9638-2311.

Cite this article as:

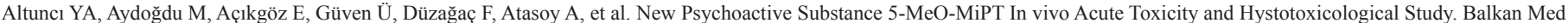
J 2021;38:34-42

Copyright@Author(s) - Available online at http://balkanmedicaljournal.org/ 
and Southeast Asian countries. NPS are frequently synthesized from derivatives of many synthetic tryptamines and then used for recreational purposes (9-11). As a result of the constant changes in the illicit drug market and the difficulty in detecting these substances through routine analytical methods, the estimated number is likely to be higher. So far about $40 \mathrm{~N}, \mathrm{~N}$-dialkylated tryptamine derivatives have been identified analytically (12).

5-Methoxy-N-methyl-N-isopropyltryptamine (5-MeO-MiPT) is an analog of the popular drug 5-methoxy-N, N-diisopropyltryptamine (5-MeO-DiPT, Foxy), and it is named "Moxy" (11). Repke et al. (10) and Shulgin and Shulgin were the first to report on 5-MeOMiPT synthesis and its psychoactive effects. Doses of 4 to $6 \mathrm{mg}$ were reportedly used for oral consumption, and for administration via inhalation, higher doses of 12 to $20 \mathrm{mg}$ were used. It has been found that the 5-methoxy group's attachment to the potency tryptamine core has increased and decreased the effects on perceptual changes in appearance. It has also been reported that N-substitutions have an effect on tryptamines' in vivo potency (13).

5-MeO-MiPT may be administered by inhalation or orally. The dose for oral administration is 4 to $6 \mathrm{mg}$, and the period of effect is 4 to 6 hours; if inhaled, the dose is 12 to $20 \mathrm{mg}$. The psychoactive effects begin 15 to 20 minutes after oral ingestion and reach a peak value between approximately 45 and 60 minutes. After approximately 10 hours, the effect starts to decrease, and recovery is recorded. If inhaled, the duration of effects is 2 to 5 hours at the time of onset, and after approximately 2 to 4 hours, symptoms disappear. Effects such as euphoria, visual distortions, increased sense of touch, relaxation, and difficulty in sleeping have been reported by users $(10,11,14)$.

5-MeO-MiPT, like many other tryptamine derivatives, is an agonist of the 5-HT2A receptor (15). It inhibits 5-HT and norepinephrine reuptake with less dopamine reuptake $(3,16)$. 5-MeO-MiPT has a relatively rare and short usage history (14). However, different reports published recently mention the increasing popularity of this substance $(1,6,7,17)$.

To date, publications on 5-MeO-MiPT consist of receptor interaction profiles (15), receptor functional data (18), case reports and determination of NPS $(14,19)$, and studies of metabolite determination by advanced analytical methods $(13,20)$.

In this paper, we report the acute toxicity of 5-MeO-MiPT in mice; therefore, mice were injected 5-MeO-MiPT intraperitoneally (IP), followed by quantitative toxicological analysis of the blood and organs and histotoxicological and immunohistochemical analyses of tissues and cells.

\section{MATERIALS AND METHODS}

\section{Reagents and chemicals}

The reference standard of 5-MeO-MiPT was bought from Lipomed Inc (Cambridge, MA). The internal standard, diazepam-d5 $10 \mu \mathrm{g} /$ $\mathrm{mL}$ in methanol $(\mathrm{MeOH})$, was purchased from Restek Corporation (Bellefonte, PA). High-performance liquid chromatography (HPLC)-grade $\mathrm{MeOH}$ and water, sodium chloride $(\mathrm{NaCl})$, acetone, dimethyl sulfoxide (DMSO), ammonium hydroxide, ethyl acetate, and ultrapure $\mathrm{MeOH}$ were bought from Merck KGaA (Darmstadt, Germany). Ammonium formate and phosphate buffer $(0.1 \mathrm{M}, \mathrm{pH}$ 4.4) was purchased from EMD Chemicals, Inc (Gibbstown, NJ). Formaldehyde, ethanol, and hydrogen peroxide $\left(\mathrm{H}_{2} \mathrm{O}_{2}\right)$ were bought from Merck KGaA (Darmstadt, Germany). Phosphate-buffered saline (PBS; pH 7.4) was purchased from Thermo Fisher Scientific (Waltham, MA). Hematoxylin and eosin (H\&E) were purchased from Sigma-Aldrich (Darmstadt, Germany). Trypsinized (2\% trypsin in $50 \mathrm{mM}$ Tris buffer) and 3,3'-diaminobenzidine (DAB; DeadEnd Colorimetric TUNEL System) were purchased from Abcam (Cambridge, UK). Caspase-3 (1:100, sc-7272) and caspase-8 (1:100, sc-56070) were purchased from Santa Cruz Biotechnology Inc (Santa Cruz, CA). Biotinylated secondary antibody and streptavidin-bound horseradish peroxidase were purchased from Zymed Laboratories Inc (South San Francisco, CA) (Histostain Plus Kit; 85-9043). Mayer's hematoxylin was purchased from Zymed Laboratories Inc (South San Francisco, CA).

\section{Experiments on animals}

In vivo animal studies were performed using 26 adult female CD1 mice aged 8 to 10 weeks and weighing 20 to $30 \mathrm{~g}$ (Kobay Experimental Animals Laboratory A.Ş., Ankara, Turkey). The study protocol was approved by the ethics committee of the Animal Experiments of the Ege University (reference no. 2017-115). All mice were maintained in a controlled 12-hour light and 12-hour dark cycle at $24^{\circ} \mathrm{C}$ and $60 \%$ humidity conditions, and all were fed ad libitum. Animals were caged in 4 independent groups in a completely randomized design. The first group was a control $(n=3)$, and nothing was injected. The second group was a vehicle control $(n=3)$ and injected $150 \mu \mathrm{L}$ of blank solution $50 \%$ DMSO in saline $(0.9 \%$ of $\mathrm{NaCl})$, whereas for acute toxicity experiments, to get a dose of $0.27 \mathrm{mg} / \mathrm{kg}$ in a $150 \mu \mathrm{L}$ injection $(\mathrm{n}=10)(20), 5-\mathrm{MeO}-\mathrm{MiPT}$ was added to a blank solution, and the last group was injected $2.7 \mathrm{mg} / \mathrm{kg} 5-\mathrm{MeO}-\mathrm{MiPT}$ in a $150 \mu \mathrm{L}$ injection $(n=10)$. All injections were applied IP.

The $0.27 \mathrm{mg} / \mathrm{kg}$ dose was estimated according to a rough quantification of 5-MeO-MiPT in pill samples in a study (20), and the same dose was administered in this study. In addition, the $2.7 \mathrm{mg} /$ $\mathrm{kg}$ dose was estimated and administered based on pharmacological studies. After 1 hour, the mice were quickly sacrificed by cervical dislocation. For the control group ( 3 animals) and the vehicle control (3 animals), blood samples were collected 60 minutes after vehicle injection (20). Blood samples were collected from the heart and abdominal cavities of the mice. The brain, kidneys, and liver were removed and stored at $-80^{\circ} \mathrm{C}$ until toxicological, histopathological, and immunohistochemical analyses were performed. The Animal Research: Reporting of In Vivo Experiments guideline was used in the reporting of animal experiments (21).

\section{Sample Treatment of Histopathological and Immunohistochemical Analysis}

\section{Histopathological analysis}

The removed organ parts were put in $4 \%$ formaldehyde in $0.1 \mathrm{M}$ PBS and histological tissue processing was applied. Then, $5-\mu \mathrm{m}-$ thick sections were cut from every sample and stained with H\&E. All samples were visualized by using an Olympus BX-51 microscope (Olympus, Japan). 


\section{Immunohistochemical analysis}

After sectioning, samples were deparaffinized, immersed in a series of ethanol solutions, and washed first with ultrapure water and then PBS for 15 minutes. Sections were trypsinized ( $2 \%$ trypsin in $50 \mathrm{mM}$ Tris buffer) for 20 minutes at $37^{\circ} \mathrm{C}$. Then, circles were drawn around tissues on slides with a hydrophobic barrier pen, and inhibition of endogenous peroxidase activity was applied on the tissues with $3 \% \mathrm{H}_{2} \mathrm{O}_{2}$ for 15 minutes. Sections were incubated with caspase- 3 and caspase- 8 in a humidity chamber at $40^{\circ} \mathrm{C}$ overnight. Then, sections were incubated with biotinylated secondary antibody for 1 hour and streptavidin-bound horseradish peroxidase for 1 hour. Sections were incubated in DAB. After counterstaining with Mayer's hematoxylin, sections were washed and visualized using an Olympus BX-51 microscope (Olympus, Japan).

\section{Semiquantitative analysis of the immunoreactivity caspase-3 and caspase-8}

Semiquantitative assessment of caspase- 3 and caspase- 8 immunoreactivity was determined using $\mathrm{H}$-score, which involves a semiquantitative assessment of the percentage of positive cells and the intensity of staining (graded as $0=$ nonstaining, $1=$ weak, $2=$ median, $3=$ strong) both. H-scores were obtained by the following formula: $1 \times(\%$ of $1+$ cells $)+2 \times(\%$ of $2+$ cells $)+3 \times(\%$ of $3+$ cells). The range of possible scores was from 0 to 300 . A total of 10 randomly selected caspase-3 and caspase-8-stained images were counted. The number of positive cells was determined by scoring at least 100 cells per 10 view fields of tissue sections while magnified at $\times 20$. The samples were evaluated by 3 different persons, independently and blinded to the final score.

\section{Statistical analysis}

Caspase- 3 and caspase- 8 immunoreactivity was calculated by statistical analysis. The Shapiro-Wilk test was used to test the normality of the distribution of the data. All groups passed the normality test ( $p>0.05)$; details are presented in the Supplemental File. Quantitative data are presented as the mean \pm standard deviation (SD) of 3 independent experiments. Caspase- 3 and caspase- 8 immunoreactivity was compared using 2-way analysis of variance (ANOVA) owing to more than 1 factor

(between the subject, 2 different doses; and within the subject, tissue sections) followed by Tukey's post hoc test using GraphPad Prism 8 (GraphPad Software, San Diego, CA). $\mathrm{p}<0.05$ was considered statistically significant.

Based on data from a pilot study, an analysis was performed for sample size estimation using PS Power and Sample Size program version 3.1 (Vanderbilt University, USA) based on a published study by Fabregat-Safont et al. (20). The type I error probability for a 2-sided test $(\alpha)$ of 0.05 , a difference in population means $(\delta)$ of $0.3, \operatorname{SD}(\sigma)$ of 0.03 , and ratio of control to experimental patients $(\mathrm{m})$ of 0.25 were used, and power was calculated at 0.999 . Thus, our sample size of $26(3=$ control, $3=$ vehicle control, $10=$ low dose, $10=$ high dose $)$ will exceed the needed number for the main goal of this study.

\section{Sample Treatment of Toxicological Analysis}

Extraction of blood samples

A total of $200 \mu \mathrm{L}$ of the blood sample was obtained. Blood samples were added to the $10 \mu \mathrm{L}$ internal standard (diazepam-d5) and $1 \mathrm{~mL}$ ultrapure water. Then, samples were centrifuged for 10 minutes at $3500 \mathrm{rpm}$ and passed through an Oasis HLB (3 cc, $60 \mathrm{mg}$, Waters Corporation, Milford, Massachusetts) solid-phase extraction cartridge. Blood samples were applied to a cartridge that had been conditioned with $2 \mathrm{~mL} \mathrm{MeOH}$ and $2 \mathrm{~mL}$ ultrapure water all at a flow rate of $1 \mathrm{~mL} / \mathrm{min}$. The samples were passed through the cartridges at a flow rate of $0.5 \mathrm{~mL} / \mathrm{min}$, which is low, and then washed in ultrapure water with $2 \mathrm{~mL} \mathrm{5 \%} \mathrm{MeOH}$ and dried under vacuum at approximately $125 \mathrm{~mm} \mathrm{Hg}$ for 5 minutes. The analytes were eluted with $2 \mathrm{~mL}$ acetone and $\mathrm{MeOH}$ mixture (70:30 v/v) and 2 $\mathrm{mL} 2 \% \mathrm{NH}_{4} \mathrm{OH}$ in ethyl acetate $(98: 2 \mathrm{v} / \mathrm{v})$. The collected eluate was concentrated to dehydration with a mild flow $(125 \mathrm{~mm} \mathrm{Hg})$ of nitrogen gas for 5 minutes. The residues were formed again in 200 $\mu \mathrm{L} \mathrm{MeOH}$, and $20 \mu \mathrm{L}$ was used for liquid chromatography with tandem mass spectrometry (LC-MS/MS) system.

\section{Extraction of tissue samples}

Each tissue sample was thawed at room temperature and aliquoted at approximately 2 to $3 \mathrm{~g} ; 100 \mathrm{mg}$ of the sample was homogenized in phosphate buffer (0.1 M, pH 4.4) (IKA Ultra-Turrax Tube Drive, Werke $\mathrm{GmbH}$, Germany), and $10 \mu \mathrm{L}$ of internal standard (diazepam-d5) was spiked to $1 \mathrm{~mL}$ of the homogenate taken from each homogenized tissue sample. Homogenates were dissolved again in $4 \mathrm{~mL}$ phosphate buffer. Later, the samples were centrifuged at $3500 \mathrm{rpm}$ for 10 minutes and the supernatants were taken. The drugs were extracted from the tissue samples by using the same extraction procedure as for blood samples; $20 \mu \mathrm{L}$ of each sample was injected into the LC-MS/MS system.

\section{Instrumentation}

All experiments were performed on LC-MS/MS for chromatographic analysis. LC-MS/MS analysis was performed on a Shimadzu CBM-20A Ultra Flow Liquid Chromatography or UFLC with a Shimadzu SIL-20A/HT autosampler system and Shimadzu 8040 LC-MS/MS systems (electrospray ionization quadrupole mass spectrometer) (Kyoto, Japan). The samples were separated by using a pentafluorophenylpropyl column Allure at $50 \times 2.150 \mathrm{~mm}$ i.d. and $5 \mu \mathrm{m}$ (Restek Corporation, Bellefonte, PA) and maintained at ambient temperature. The mobile phase consisted of ultrapure water with $10 \mathrm{mM}$ ammonium formate (solution A) and $\mathrm{MeOH}$ (solution B). The gradient was started for the positive mode with $10 \% \mathrm{~B}$ and held for 10 minutes at a flow rate of $0.5 \mathrm{~mL} / \mathrm{min}$; then, the flow rate was increased to $1 \mathrm{~mL} / \mathrm{min}$ with $90 \% \mathrm{~B}$ and kept at these conditions for 5 minutes. After 15 minutes, the flow rate was set back to $0.5 \mathrm{~mL} /$ min with $10 \% \mathrm{~B}$. The HPLC eluent was diverted to waste for the first 1.5 minutes. The total run time per sample was 18 minutes. LC-

TABLE 1. LC-MS/MS parameters for the MRM acquisition mode

\begin{tabular}{llllll}
\hline Compound & Retention time & Precursor ion & Product ions & CE & ESI \\
\hline \multirow{2}{*}{ 5-MeO-MiPT } & \multirow{2}{*}{11.4} & & 86.10 & -15 & + \\
& & 246.80 & 174.10 & $-16+$ \\
& & 159.10 & $-30+$ \\
\hline
\end{tabular}

CE: collision energy, ESI: electrospray ionization, LC-MS/MS: liquid chromatography with tandem mass spectrometry, 5-MeO-MiPT: 5-methoxy-N-methyl-N-isopropyltryptamine, MRM: multiple reaction monitoring 


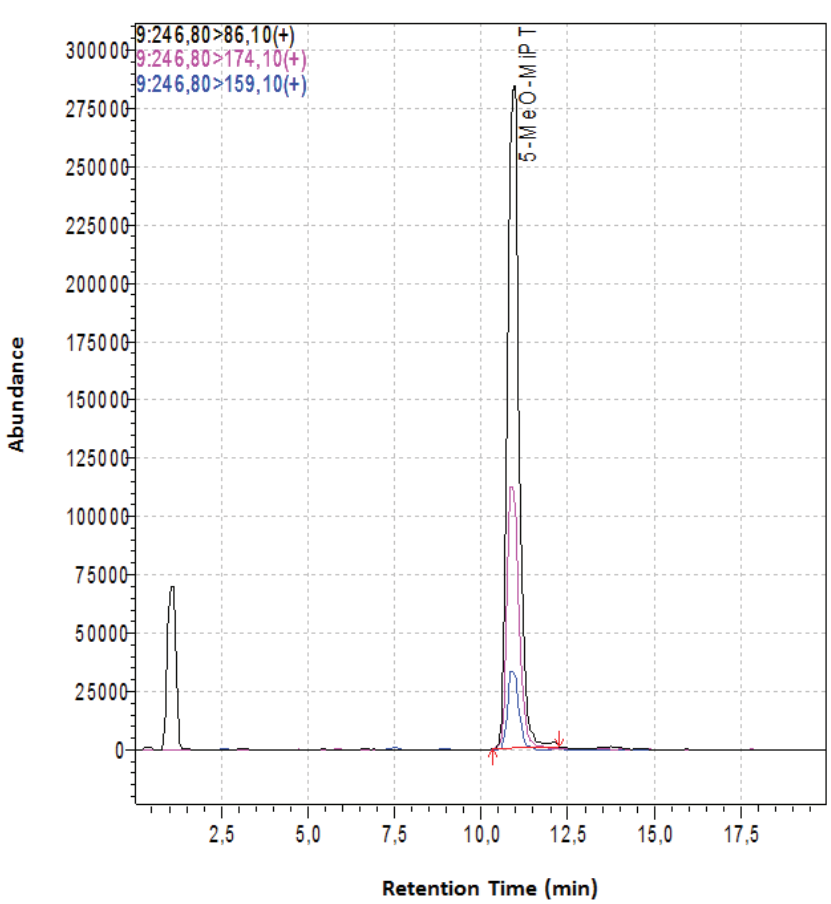

FIG. 1. 5-MeO-MiPT chromatogram and ions.

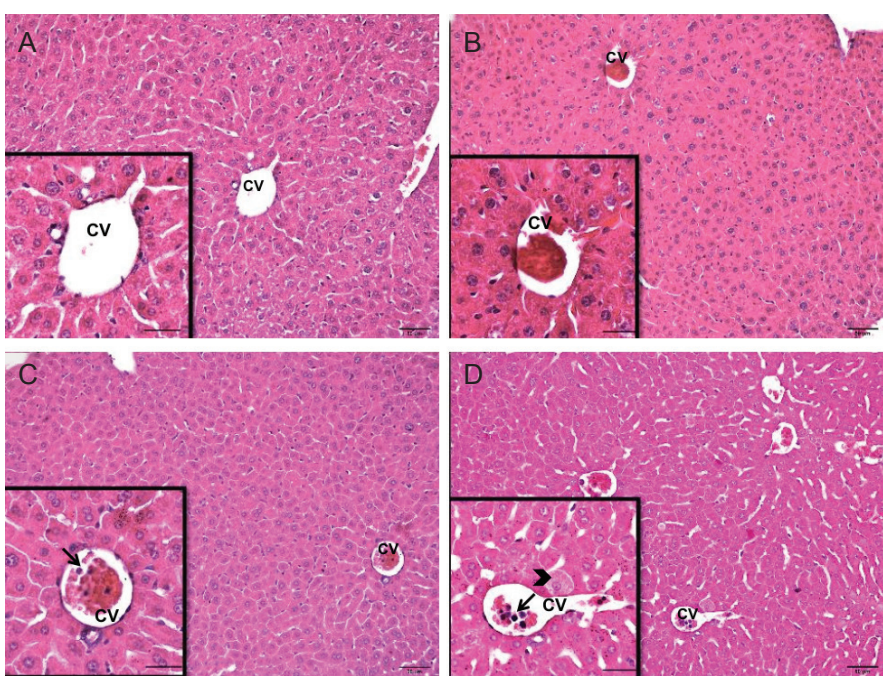

FIG. 2. A-D. The histological sections of mice liver stained by H\&E. A) Control group, B) Vehicle control, C) $0.27 \mathrm{mg} / \mathrm{kg} 5-\mathrm{MeO}-\mathrm{MiPT}$ group, D) $2.7 \mathrm{mg} / \mathrm{kg}$ 5-MeO-MiPT H\&E staining. Arrowhead indicates hepatocyte swelling, arrows point to immune cell infiltration. CV: central vein. Scale bar: $50 \mu \mathrm{m}$; inset scale bar, $20 \mu \mathrm{m}$

MS/MS parameters established for the multiple reaction monitoring acquisition mode are presented in Table 1 and Figure 1.

Working solutions were prepared by diluting the reference standards in different ratios with $\mathrm{MeOH}$ that was used for the preparation of the calibration points. By spiking $190 \mu \mathrm{L}$ blank blood samples with $10 \mu \mathrm{L}$ of the working solution, calibration samples with concentrations of $1,2.5,5,10,25$, and $50 \mathrm{ng} / \mathrm{mL}$ were ob-
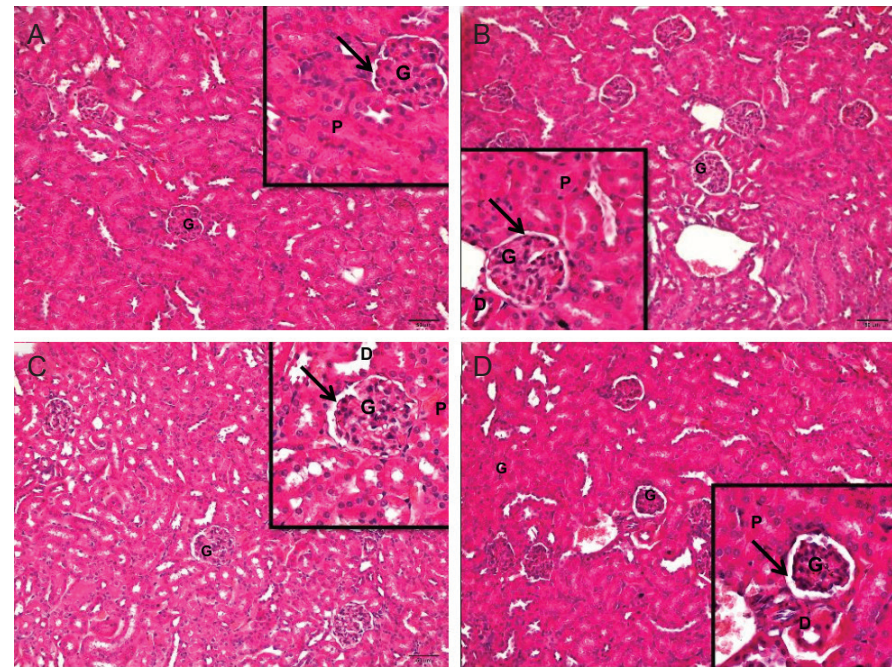

FIG. 3. A-D. The histological sections of mice kidney stained by H\&E. A) Control group, B) Vehicle control, C) $0.27 \mathrm{mg} / \mathrm{kg}$ 5-MeO-MiPT group, D) 2.7 $\mathrm{mg} / \mathrm{kg}$ 5-MeO-MiPT H\&E staining. Arrows indicate Bowman's Space. Renal structures indicated as glomerulus $(G)$, proximal tubule $(P)$, distal tubule (D). Scale bar: $50 \mu \mathrm{m}$; inset scale bar, $20 \mu \mathrm{m}$

tained. For tissue samples, by spiking $190 \mu \mathrm{L}$ blank homogenizing samples with $10 \mu \mathrm{L}$ of the working solution, calibration samples with concentrations of $1,2.5,5,25$, and $50 \mathrm{ng} / \mathrm{g}$ were obtained.

\section{RESULTS}

\section{Histological Results}

Histological examination of the mice in control and vehicle controls revealed the normal architecture of hepatic lobules consisting of hepatic cords radiating from a central vein toward the lobular periphery, portal vein, and sinusoids (Figure 2. a, b). After administration of 5-MeO-MiPT, it was determined that the normal histological structure of the liver was preserved (Figure 2. c, d). Only mild nonspecific immune cell inflammation was observed, especially in the portal track areas and the central vein for low and high doses of 5-MeO-MiPT (Figure 2. c, d). At larger microscopic magnification, lymphocytes between red blood cells appear as darkstained objects. The dark-stained (basophilic) pattern corresponds to the nuclei of the lymphocytes (Figure 2. c, d). In addition, a mild degree of degeneration and cytoplasm swelling of the hepatocytes characterized by a paler pink color were seen in high-dose $5-\mathrm{MeO}-$ MiPT $(2.7 \mathrm{mg} / \mathrm{kg}$ ) (Figure 2d).

The kidney sections of all mice groups showed normal histological structures of the glomeruli and renal tubules (proximal and distal) in the cortical and medullary portions (Figure 3 ). The glomerulus is the conspicuous tiny ball-shaped structure. Deformations of the glomerulus structures of the kidney were determined in high-dose $5-\mathrm{MeO}-\mathrm{MiPT}(2.7 \mathrm{mg} / \mathrm{kg}$ ) (Figure 3d). For the high-dose 5-MeOMiPT, although not very obvious, glomeruli shrinkage and dilatation of Bowman's spaces were observed.

Light microscopic examination of the H\&E-dyed sections of the brain tissues of different groups of animals is depicted in Figure 4. Brain tissue sections of mice showed normal neurons with dense 

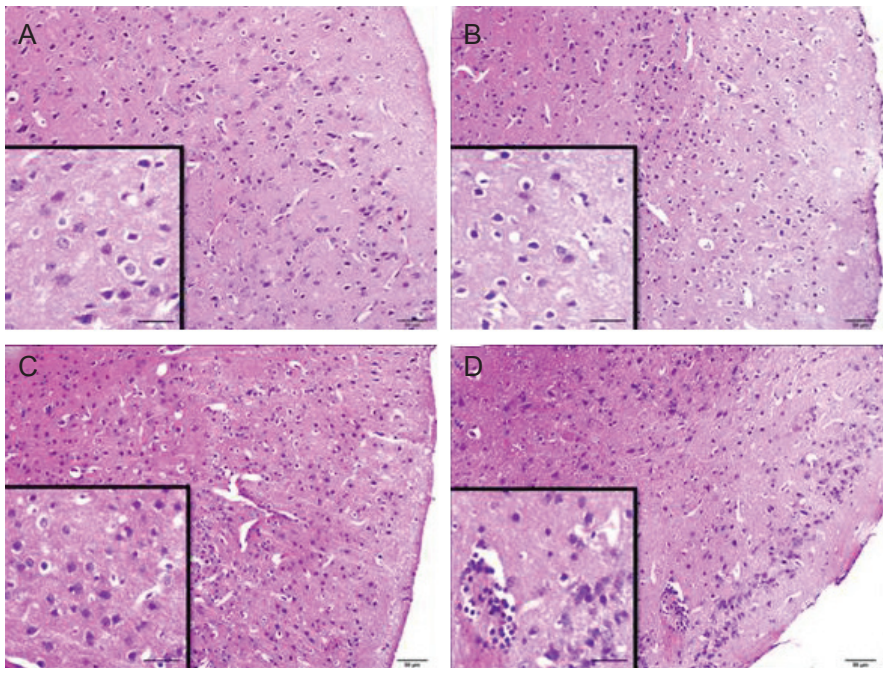

FIG. 4. A-D. The histological sections of mice brain stained by H\&E. A) Control group, B) Vehicle control, C) $0.27 \mathrm{mg} / \mathrm{kg}$ group, D) $2.7 \mathrm{mg} / \mathrm{kg} 5-\mathrm{MeO}-$ MiPT H\&E staining, Scale bar: $50 \mu \mathrm{m}$; inset scale bar, $20 \mu \mathrm{m}$
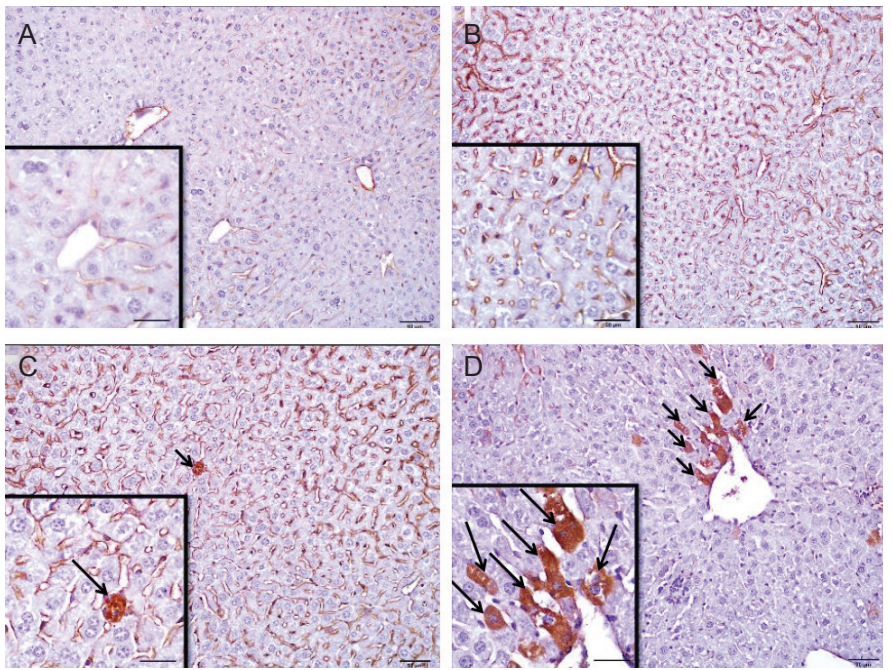

FIG. 5. A-D. Immunoreactivity of caspase-3 in liver. A) Control group, B) Vehicle control, C) $0.27 \mathrm{mg} / \mathrm{kg}$ 5-MeO-MiPT group, D) $2.7 \mathrm{mg} / \mathrm{kg} 5-\mathrm{MeO}-\mathrm{MiPT}$ IHC staining. Brown staining represented by black arrows show caspase-3 positive cells. Scale bar: $50 \mu \mathrm{m}$; inset scale bar, $20 \mu \mathrm{m}$

basophilic cytoplasm. After the administration of 5-MeO-MiPT, no histological alterations were detected.

\section{Immunohistochemical results}

The immunohistochemical assay was used to determine the expression patterns of caspase- 3 and caspase- 8 in the kidney, liver, and brain tissues. A 2-way ANOVA was used to compare staining intensities of caspase- 3 and caspase-8, and Tukey's post hoc test was done to determine the important differences between individual intensities. Caspase- 3 and caspase- 8 immunoreactivities were evaluated considering brown (DAP) and blue (hematoxylin) staining areas. The brown DAP staining pattern showed positive caspase-3 and caspase- 8 immunoreactivity. In the liver, kidney, and brain sections, there was no expression of caspase- 3 in the observed nor-
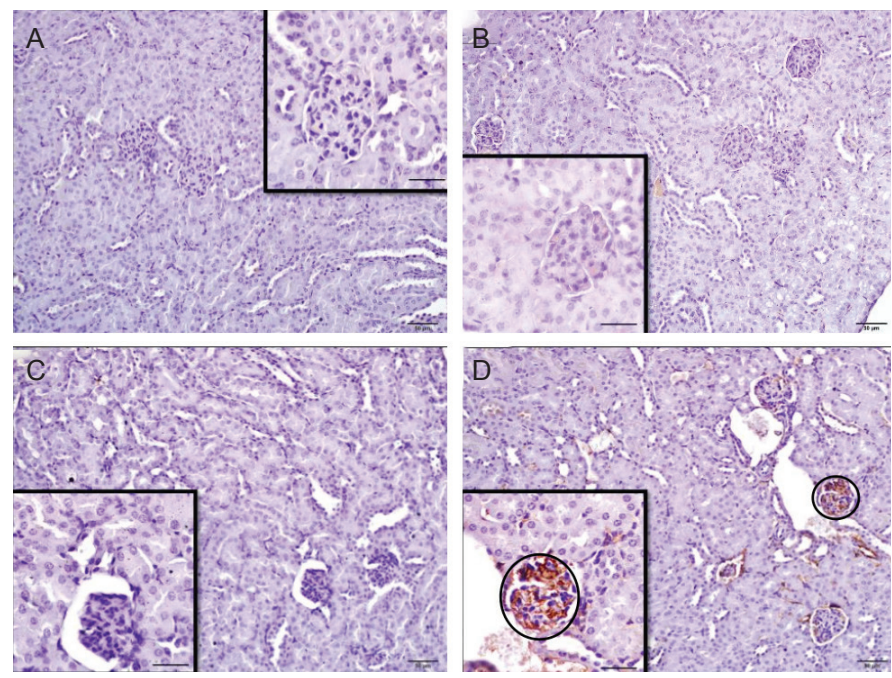

FIG. 6. A-D. Immunoreactivity of caspase-3 in kidney. A) Control group, B) Vehicle control, C) $0.27 \mathrm{mg} / \mathrm{kg} 5-\mathrm{MeO}-\mathrm{MiPT}$ group, D) $2.7 \mathrm{mg} / \mathrm{kg} 5-\mathrm{MeO}$ MiPT IHC staining. The areas within the black circles indicate caspase- 3 positive cells in the glomerular structure. Scale bar: $50 \mu \mathrm{m}$; inset scale bar, $20 \mu \mathrm{m}$

mal tissues (Figures 5a, 6a, and 7a). In the vehicle control liver section, caspase-3 staining appeared similar to that of normal tissues (Figure 5b). No statistically significant difference was seen in the results obtained from semiquantitative evaluation (Graph 1) $(\mathrm{p}>0.05)$. In the low-dose 5-MeO-MiPT liver section, it was found that the number of caspase-3 positive cells, whose cytoplasm was stained brown (Figure 5c), was quite low. Compared with normal tissues, the difference in staining was statistically significant (Graph 1). When exposed to high-dose 5-MeO-MiPT, significant caspase-3 immunoreactivity was observed in hepatocytes (Figure 5D). In high-dose 5-MeO-MiPT, a large increase in cells that were stained intensely with caspase- 3 was detected. An analysis of the results obtained from the $\mathrm{H}$-score showed that the increase in the number of caspase-3 positive cells was significant compared with the control (Figure 11) $(\mathrm{p}<0.05)$. In the kidney tissues, caspase-3 positive cells were found in the glomeruli. In the vehicle control kidney sections and low-dose 5-MeO-MiPT, caspase-3 staining appeared similar (Figure 6. b, c). In high-dose 5-MeO-MiPT, especially in the glomerular structure, intense caspase-3 immunoreactivity was observed (Figure 6d), and the increase in the number of caspase-3 positive cells compared with the control was statistically significant (Graph 1) $(\mathrm{p}<0.05)$. In the brain section, there were a few caspase-3 positive cells characterized by a light brown staining pattern in high-dose 5-MeO-MiPT (Figure 7d). An analysis of the results obtained from the $\mathrm{H}$-score showed that the rising number of caspase-3 positive cells was significant compared with the control (Graph 1) ( $\mathrm{p}=0.0183)$. However, there was low level of caspase-3 immunoreactivity in the low-dose 5-MeO-MiPT brain sections (Figure 7c), and the increase in caspase-3 immunoreactivity was not statistically significant $(\mathrm{p}>0.05)$.

Caspase- 8 staining showed a similar pattern to caspase- 3 , and the cytoplasmic areas were found to be stained within the cell. In the liver, kidney, and brain sections, there was no immunoreac- 
TABLE 2. The method parameters

\begin{tabular}{|c|c|c|c|c|c|c|c|}
\hline \multirow[b]{2}{*}{ Compound } & \multirow[b]{2}{*}{ Retention time } & \multirow{2}{*}{$\begin{array}{c}\text { Tissue } \\
\mathrm{R}^{2}\end{array}$} & \multicolumn{5}{|c|}{ Blood } \\
\hline & & & LOD & LOQ & $\mathrm{R}^{2}$ & LOD & LOQ \\
\hline 5-MeO-MiPT & 11.4 & 0.997 & $0.3 \mathrm{ng} / \mathrm{g}$ & $0.9 \mathrm{ng} / \mathrm{g}$ & 0.997 & $1.5 \mathrm{ng} / \mathrm{mL}$ & $4.5 \mathrm{ng} / \mathrm{mL}$ \\
\hline
\end{tabular}
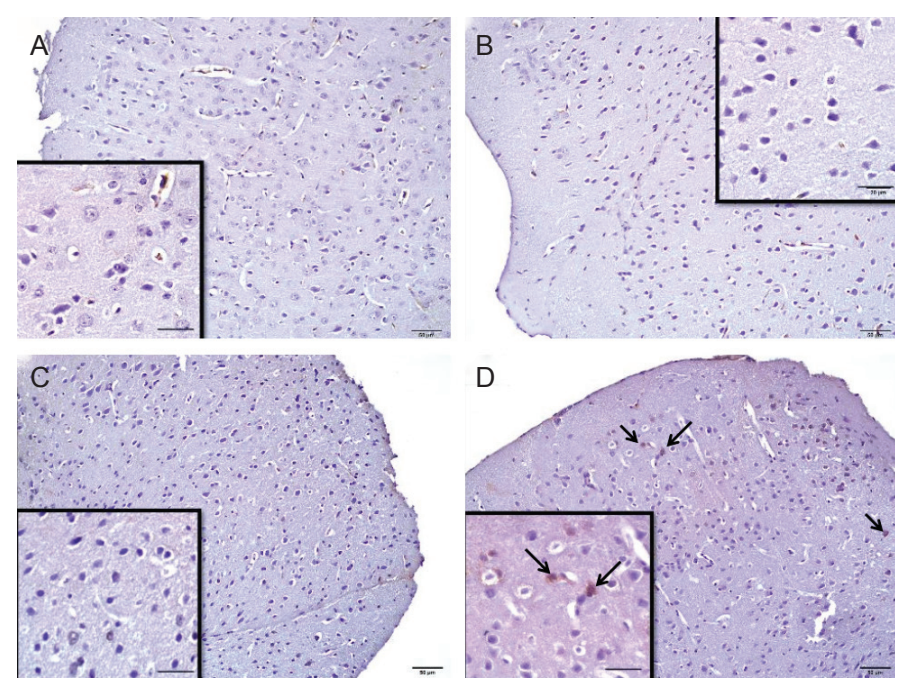

FIG. 7. A-D. Immunoreactivity of caspase-3 in brain. A) Control group, B) Vehicle control, C) $0.27 \mathrm{mg} / \mathrm{kg}$ 5-MeO-MiPT group, D) $2.7 \mathrm{mg} / \mathrm{kg}$ 5-MeO-MiPT $\mathrm{IHC}$ staining. Brown staining represented by black arrows indicate caspase-3 positive cells. Scale bar: $50 \mu \mathrm{m}$; inset scale bar, $20 \mu \mathrm{m}$
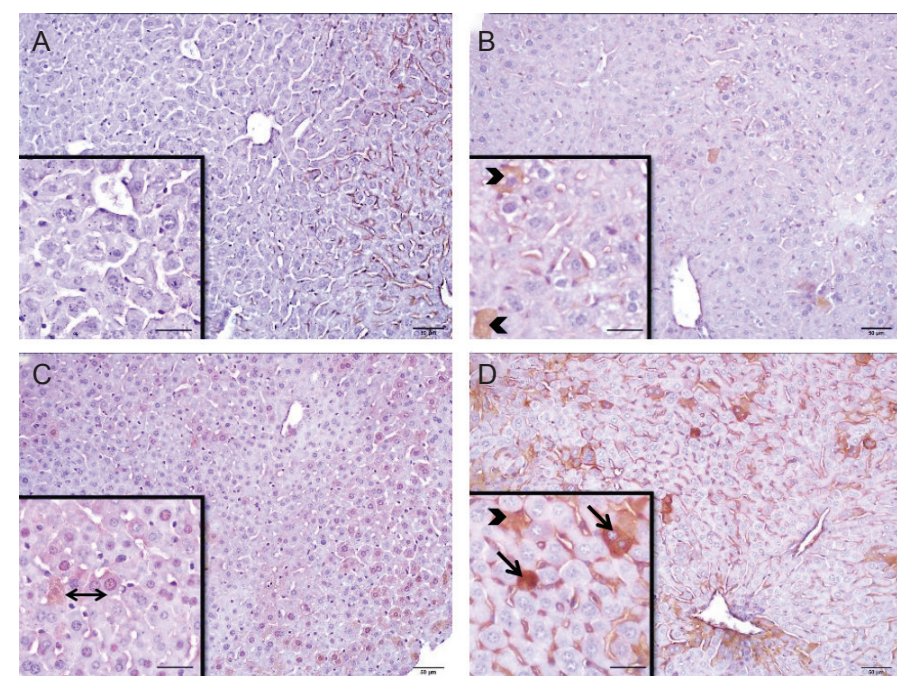

FIG. 8. A-D. Immunoreactivity of caspase-8 in liver. A) Control group, B) Vehicle control, C) $0.27 \mathrm{mg} / \mathrm{kg}$ 5-MeO-MiPT group, D) $2.7 \mathrm{mg} / \mathrm{kg} \mathrm{5-MeO-MiPT} \mathrm{IHC}$ staining. Scale bar: $50 \mu \mathrm{m}$; inset scale bar, $20 \mu \mathrm{m}$

tivity of caspase- 8 in the observed control tissues (Figures $8 \mathrm{a}$, $9 \mathrm{a}$, and 10a). In the vehicle control liver section, there were a few caspase- 8 positive cells characterized by a light brown appearance (Figure 8b) $(\mathrm{p}=0.0117)$. The low-dose 5-MeO-MiPT group revealed a weak positivity forcaspase- 8 in the liver sec-

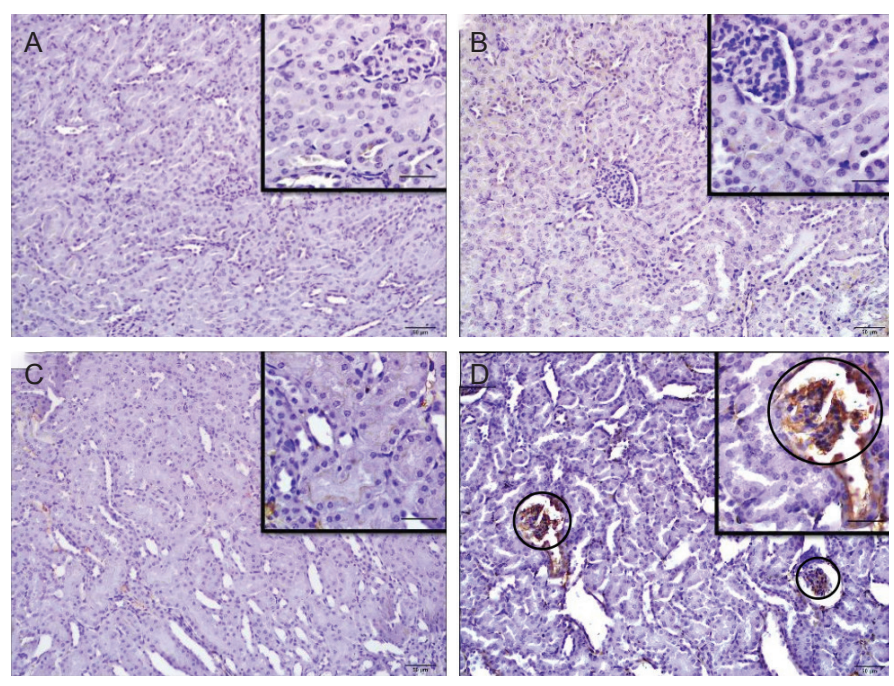

FIG. 9. A-D. Immunoreactivity of caspase-8 in kidney. A) Control group, B) Vehicle control, C) $0.27 \mathrm{mg} / \mathrm{kg}$ 5-MeO-MiPT group, D) $2.7 \mathrm{mg} / \mathrm{kg} \mathrm{5-MeO-MiPT} \mathrm{IHC}$ staining. The areas within the black circles indicate caspase-8 positive cells in the glomerular structure. Scale bar: $50 \mu \mathrm{m}$; inset scale bar, $20 \mu \mathrm{m}$
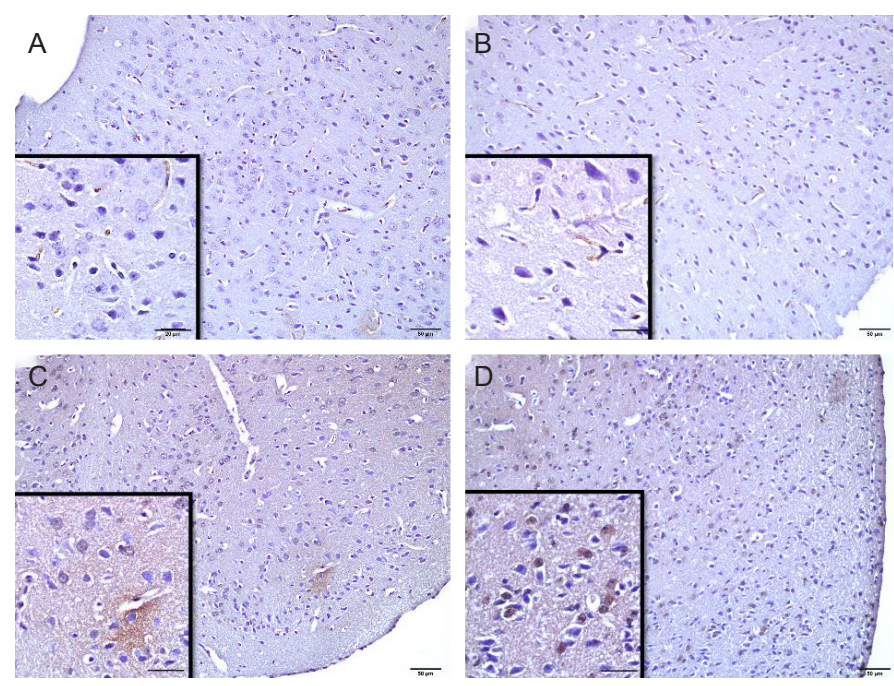

FIG. 10. A-D. Immunoreactivity of caspase-8 in brain. A) Control group, B) Vehicle control, C) $0.27 \mathrm{mg} / \mathrm{kg} 5-\mathrm{MeO}-\mathrm{MiPT}$ group, D) $2.7 \mathrm{mg} / \mathrm{kg} 5-\mathrm{MeO}-$ MiPT IHC staining, Scale bar: $50 \mu \mathrm{m}$; inset scale bar, $20 \mu \mathrm{m}$

tions (Figure 8c). In the high-dose 5-MeO-MiPT group, a rise in the number of medium and intense caspase-8-stained cells was detected. The number of positive cells in the low- and high-dose 5-MeO-MiPT groups was statistically significant compared with the control (Graph 1) $(\mathrm{p}<0.05)$. In the kidney tissue, except for 
a

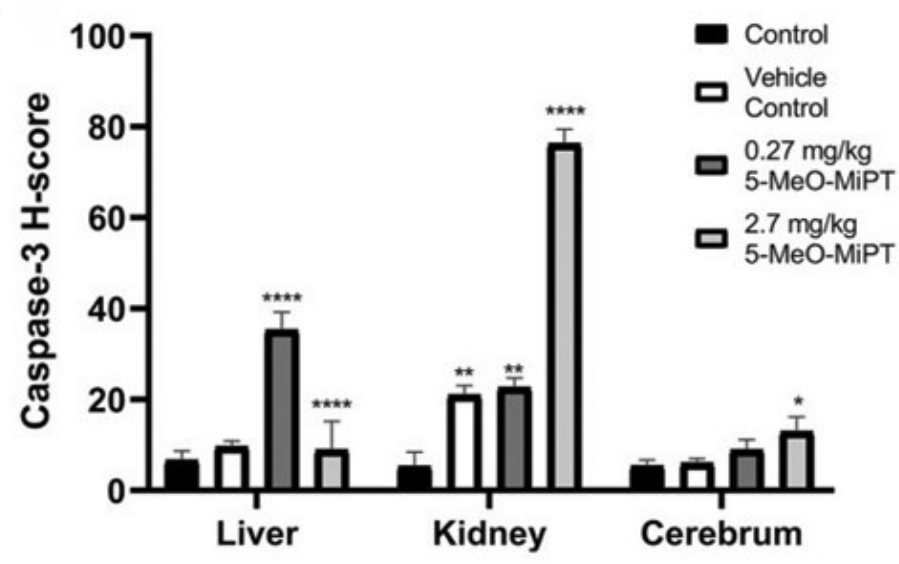

\begin{tabular}{|c|c|c|}
\hline \multicolumn{2}{|r|}{ Comparison } & \multirow{2}{*}{$\begin{array}{c}\begin{array}{c}\text { Multiplicity } \\
\text { Adjusted P } \\
\text { Value* }\end{array} \\
<0.0001 \\
\end{array}$} \\
\hline \multirow[t]{4}{*}{ Liver } & Control vs $0.27 \mathrm{mg} / \mathrm{kg} 5$-meo-MIPT & \\
\hline & Control vs $2.7 \mathrm{mg} / \mathrm{kg} 5$-meo-MIPT & $<0.0001$ \\
\hline & $\begin{array}{l}\text { Vehicle control vs } 0.27 \mathrm{mg} / \mathrm{kg} 5 \text { - } \\
\text { meo-MiPT }\end{array}$ & $<0.0001$ \\
\hline & $\begin{array}{l}\text { Vehicle control vs } 2.7 \mathrm{mg} / \mathrm{kg} \text { 5-meo- } \\
\text { MIPT }\end{array}$ & $<0.0001$ \\
\hline \multirow{4}{*}{ Kidney } & Control vs Vehicle control & 0.0013 \\
\hline & Control vs $0.27 \mathrm{mg} / \mathrm{kg} 5$-meo-MIPT & 0.0013 \\
\hline & Control vs $2.7 \mathrm{mg} / \mathrm{kg}$ 5-meo-MIPT & $<0.0001$ \\
\hline & $\begin{array}{l}\text { Vehicle control vs } 2.7 \mathrm{mg} / \mathrm{kg} \text { 5-meo- } \\
\text { MIPT }\end{array}$ & $<0.0001$ \\
\hline \multirow[b]{2}{*}{ Cerebrum } & Control vs $2.7 \mathrm{mg} / \mathrm{kg}$ 5-meo-MIPT & 0.0299 \\
\hline & $\begin{array}{l}\text { Vehicle control vs } 2.7 \mathrm{mg} / \mathrm{kg} 5 \text {-meo- } \\
\text { MIPT }\end{array}$ & 0.0131 \\
\hline
\end{tabular}

b

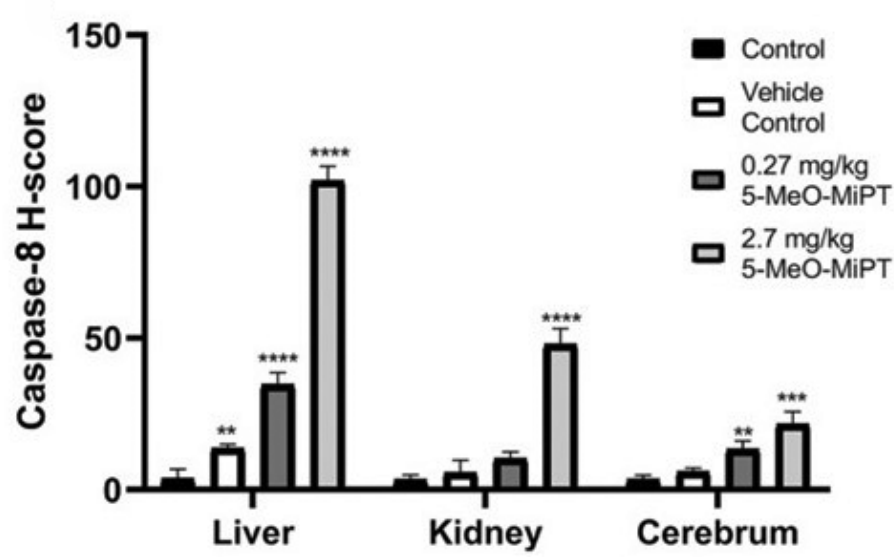

\begin{tabular}{|c|c|c|}
\hline & Comparison & $\begin{array}{c}\text { Multiplicity } \\
\text { Adjusted P } \\
\text { Value* }\end{array}$ \\
\hline \multirow{5}{*}{ Liver } & Control vs Vehicle control & 0.0117 \\
\hline & Control vs $0.27 \mathrm{mg} / \mathrm{kg}$ 5-meo-MiPT & $<0.0001$ \\
\hline & Control vs $2.7 \mathrm{mg} / \mathrm{kg}$ 5-meo-MIPT & $<0.0001$ \\
\hline & Vehicle control vs $0.27 \mathrm{mg} / \mathrm{kg}$ 5-meo-MIPT & $<0.0001$ \\
\hline & Vehicle control vs $2.7 \mathrm{mg} / \mathrm{kg} 5$-meo-MiPT & $<0.0001$ \\
\hline \multirow{3}{*}{ Kidney } & Control vs $2.7 \mathrm{mg} / \mathrm{kg}$ 5-meo-MIPT & $<0.0001$ \\
\hline & Vehicle control vs $0.27 \mathrm{mg} / \mathrm{kg}$ 5-meo-MIPT & $<0.0001$ \\
\hline & Vehicle control vs $2.7 \mathrm{mg} / \mathrm{kg}$ 5-meo-MiPT & $<0.0001$ \\
\hline \multirow{3}{*}{ Cerebrum } & Control vs $0.27 \mathrm{mg} / \mathrm{kg} 5$-meo-MiPT & 0.0079 \\
\hline & Control vs $2.7 \mathrm{mg} / \mathrm{kg}$ 5-meo-MIPT & 0.0002 \\
\hline & Vehicle control vs $2.7 \mathrm{mg} / \mathrm{kg} 5$-meo-MiPT & 0.0008 \\
\hline \multicolumn{3}{|c|}{${ }^{*}$ Comparison with $\mathrm{p}>0.05$ are not shown } \\
\hline
\end{tabular}

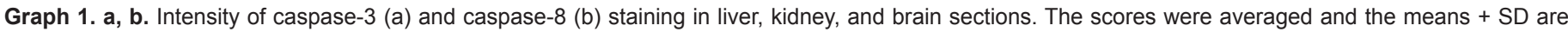

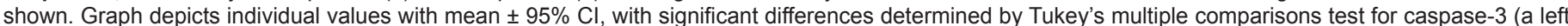
panel) and caspase-8 (b left panel) staining shown in the table.

the high-dose 5-MeO-MiPT, there was no significant increase in caspase-8 immunoreactivity (Figures 9 and 11). In the high-dose 5-MeO-MiPT group, caspase- 8 immunoreactivity was detected in the glomerular structures (Figure 9d). Compared with control, the increase in caspase- 8 immunoreactivity was found to be statistically significant (Graph 1$)(\mathrm{p}<0.05)$. In the cerebellum sections, medium and weak caspase-8-stained cells were detected in low- and high-dose 5-MeO-MiPT groups (Figure 10. c, d).

\section{Toxicological results}

Chromatographic method parameters and chromatogram for 5-MeO-MiPT parent drug after pretreatment of blood and tissue samples are presented in Tables 1 and 2 and Figure 1.

All biological samples were analyzed using the method mentioned earlier. 5-MeO-MiPT results in all control and vehicle control samples were negative (below the limit of quantification [LOQ] level). 5-MeO-MiPT, the parent drug, tested negative (below the LOQ level) in biological samples of $0.27 \mathrm{mg} / \mathrm{kg}$ dose mice; In the 2.7 $\mathrm{mg} / \mathrm{kg}$ dose injected mice, blood analysis results were found to be between 2.7 and $13.4 \mathrm{ng} / \mathrm{mL}$. 5-MeO-MiPT was found to be 11 to $29 \mathrm{ng} / \mathrm{g}$ in the kidney, 15.2 to $108.3 \mathrm{ng} / \mathrm{g}$ in the liver, and 1.5 to $40.6 \mathrm{ng} / \mathrm{g}$ in the brain. Urine samples were collected with PBS, and 5-MeO-MiPT was found to be below the LOQ value. Because we do not have reference standards for the metabolites of 5-MeOMiPT, metabolites could not be detected in the biological samples.

\section{DISCUSSION}

Nowadays, almost every day, a new NPS is produced, and these substances, which are illegal in forensic medicine, pose a significant health threat. The hallucinogenic tryptamine analog that we analyzed in our study, together with piperazine and phenethylamine derivatives, causes social problems worldwide (22). The identification of these substances, whether used intentionally or unintentionally, is imperative and important for forensic toxicologists. To evaluate these abusive substances, the substances and their metabolites are determined in human samples. It is absolutely necessary to elucidate the metabolic pathways of a new substance in the bazaar and to ensure their accurate and reliable identification by selecting the appropriate analytical method. However, although there are several studies on the metabolism of hallucinogenic tryptamine analogs in humans, there are no studies in the literature on acute toxicity $(13,22)$. 
Even though hallucinogens are mostly evaluated as safe molecules, in recent years, poisoning and death have been reported because of the use of recreational tryptamines. Therefore, further research on the toxicology of synthetic tryptamines is needed to understand their true potential hazard (9).

In recreational use of tryptamines, small amounts of intake are sufficient to produce psychotropic phenomena. However, it has been linked with poisoning and death for various reasons, including low toxic concentrations. These molecules cannot be routinely detected by typical screening panels, so tests, especially in emergency and clinical wards, result in a false negative, leading to inaccurate or limited assessment of illegal and controlled substances and inaccuracies in diagnosis and treatment, in the context of legal regulations. It is very important for experts to provide information on these substances for public health and public safety (11). Furthermore, these compounds are difficult to detect in biological samples for determining the origin of poisoning or use. The main obstacle is in the content of the target compound, which in most cases is not known by the analyst.

In this study, as expected, no 5-MeO-MiPT was detected in the control and vehicle control groups. In low doses, however, 5-MeOMiPT was unfortunately not detectable by our analytical method. Compatible with our study, Fabregat-Safont et al. (20) stated that $0.27 \mathrm{mg} / \mathrm{kg}$ IP injection of 5-MeO-MiPT was swiftly metabolized, being nearly completely removed from the bloodstream after 60 minutes and transformed to many metabolites. However, in groups that were injected with high doses, 5-MeO-MiPT distribution was seen in the main organs of mice such as the kidney, liver, and brain. Because we do not have reference standards for metabolites of 5-MeO-MiPT, metabolites could not be detected in the biological samples. We could not find any literature on the detection of 5-MeO-MiPT in organs.

Mice were used in this study to evaluate acute toxicity related to 5-MeO-MiPT. Little is known about the human metabolism and toxicity of 5-MeO-MiPT in the assessment of potential harm to humans. Undoubtedly, the most accurate information can be obtained through studies on human beings, but human data are limited to individual poisoning cases. Ethical challenges in conducting clinical trials of these substances are restrictive in accessing this information. At this stage, in vitro experiments using microsomes or cell cultures and in vivo experiments animal models are most commonly used to generate a potential consumption marker (20).

Our study data showed that low-dose 5-MeO-MiPT did not cause any serious histopathological effects on the liver, kidney, and brain. High doses induce apoptotic cell death through caspase activity in some parts of the organs, especially the glomeruli, central vein, and portal areas. In this study, the effects on the liver, kidney, and brain have been demonstrated. Studies on the analysis of the amount of NPS in the serum and urine have been identified. Unfortunately, the literature on the effects of NPS exposure at organ level seems to be very limited. The effects of NPS on the brain have been shown in several studies $(23,24)$.

In this study, it has been shown that high doses of 5-MeO-MiPT may cause some histopathological effects in different organs (brain, liver, and kidney). Furthermore, a high-dose 5-MeO-
MiPT that induces apoptotic cell death has been investigated. The appearance of caspase activity at high doses in a short time is quite a surprise. The time between initiation of apoptosis and completion may be as short as 2 to 3 hours (25). Apoptosis plays a critical role in maintaining normal growth and hemostasis and regulating cell population balance in tissues (24). Normal tissues have caspase activity, even at low expression levels $(26,27)$. Therefore, we think that high doses of 5-MeO-MiPT accelerate the normal apoptotic process in the tissues. There are very controversial results in the literature on the effects of tryptamine analogs. 5-Meo-DMT has been shown to increase proliferation, survival, and maturation of neurons (28). However, there are data in the literature indicating that it has negative effects on brain cells and triggers cell death. In a study by Herrera et al., (23) tryptamine has been shown to trigger cell death in the neuron and glia cells. In addition, 5-MeO-DiPT has been shown to induce the development of oxidative stress, leading to neurotoxic effects (24). Our study showed that 5-MeO-MiPT, especially in high doses, triggered apoptotic cell death from increased caspase- 3 and caspase- 8 activity. However, more detailed analyses are needed to fully elucidate the effects of the drug on cell death.

So far, most publications on 5-MeO-MiPT have concentrated on the profiles of receptor interaction, in vitro studies, and case reports. Owing to biotransformation of NPS, the metabolites produced cannot be easily and rapidly identified, and the absence of reference standards is a general problem for laboratories that perform toxicological analysis. This study presents simple and basic histotoxicological information about 5-MeO-MiPT acute toxicity in an in vivo mice model, which may lead to similar analysis in postmortem cases. We may not be able to measure the metabolite 5-MeO-MiPT, which is a limitation of this study, but analyzing postmortem tissue substance levels besides blood and urine is an important forensic aspect (11).

Ethics Committee Approval: Ethics committee approval was received for this study from the Ethics Committee of the Animal Experiments of the Ege University (reference no. 2017-115).

\section{Patient Consent for Publication: N/A.}

Acknowledgement: Poster presentation at $57^{\text {th }}$ Annual Meeting of the International Association of Forensic Toxicologists (TIAFT) in Birmingham, UK. Which took place $2^{\text {nd }}-6^{\text {th }}$ September 2019

Author Contributions: Concept - S.A.A.; Design - N.D.; Supervision - S.A.A., Y.A.A.; Resources - N.D.; Materials - E.A., Ü.G., F.D.; Data Collection and/or Processing - Ü.G., F.D., A.A., E.A.; Analysis and/or Interpretation - M.A., E.A., Ü.G., F.D., A.A.; Literature Search - Y.A.A., M.A., A.A., E.A.; Writing Manuscript - Y.A.A., M.A.; Critical Review N.D., A.A., S.A.A., E.A., M.A., Y.A.A., Ü.G., F.D.

Data-sharing Statement: N/A.

Conflict of Interest: The authors have no conflicts of interest to declare.

Funding: The authors declared that this study has received no financial support.

\section{REFERENCES}

1. Soussan C, Kjellgren A. The users of Novel Psychoactive Substances: Online survey about their characteristics, attitudes and motivations. Int J Drug Policy 2016;32:77-84. [Crossref]

2. Liechti M. Novel psychoactive substances (designer drugs): Overview and pharmacology of modulators of monoamine signaling. Swiss Med Wkly 2015;145:w14043. doi: 10.4414/smw.2015.14043. [Crossref] 
3. Nagai F, Nonaka R, Satoh Hisashi Kamimura K. The effects of non-medically used psychoactive drugs on monoamine neurotransmission in rat brain. Eur J Pharmacol 2007;559:132-7. [Crossref]

4. Deluca P, Davey Z, Corazza O, Furia LD, Farre M, Flesland LH, et al. Identifying emerging trends in recreational drug use; outcomes from the Psychonaut Web Mapping Project. Prog NeuroPsychopharmacology Biol Psychiatry 2012;39:221-6. [Crossref]

5. Hondebrink L, Nugteren-van Lonkhuyzen JJ, Van Der Gouwe D, Brunt TM. Monitoring new psychoactive substances (NPS) in the Netherlands: Data from the drug market and the Poisons Information Centre. Drug Alcohol Depend 2015;147:109-15. [Crossref]

6. Corazza O, Assi S, Malekianragheb S, Beni MN, Bigdeli I, Aslanpour Z, et al. Monitoring novel psychoactive substances allegedly offered online for sale in Persian and Arabic languages. Int J Drug Policy 2014;25:724-6. [Crossref]

7. Göl E, Çok I. New psychoactive substances in Turkey: Narcotics cases assessed by the Council of Forensic Medicine between 2016 and 2017 in Ankara, Turkey. Forensic Sci Int 2019;294:113-23. [Crossref]

8. Hill SL, Thomas SHL. Clinical toxicology of newer recreational drugs. Clin Toxicol. 2011;49:705-19. [Crossref]

9. Araújo AM, Carvalho F, Bastos M de L, Guedes de Pinho P, Carvalho M. The hallucinogenic world of tryptamines: an updated review. Arch Toxicol 2015;89:1151-73. [Crossref]

10. Shulgin A, Shulgin A. TIHKAL. The Continuation.; 1st ed. Berkeley, CA: Dan Joy; 1997.

11. Tittarelli R, Mannocchi G, Pantano F, Romolo F. Recreational use, analysis and toxicity of tryptamines. Curr Neuropharmacol 2014;13:26-46. [Crossref]

12. Brandt SD, Martins CPB. Analytical methods for psychoactive N,N-dialkylated tryptamines. TrAC - Trends Anal Chem 2010;29:858-69. [Crossref]

13. Grafinger KE, Hädener M, König S, Weinmann W. Study of the in vitro and in vivo metabolism of the tryptamine 5-MeO-MiPT using human liver microsomes and real case samples. Drug Test Anal 2018;10:562-74. [Crossref]

14. Shimizu E, Watanabe H, Kojima T, Hagiwara H, Fujisaki M, Miyatake R et al. Combined intoxication with methylone and 5-MeO-MiPT. Prog Neuro-Psychopharmacology Biol Psychiatry 2007;31:288-91. [Crossref]

15. Rickli A, Moning OD, Hoener MC, Liechti ME. Receptor interaction profiles of novel psychoactive tryptamines compared with classic hallucinogens. Eur Neuropsychopharmacol. 2016;26:1327-37. [Crossref]

16. Fantegrossi WE, Harrington AW, Kiessel CL, Eckler JR, Rabin RA, Winter JC, et al. Hallucinogenlike actions of 5-methoxy-N, N-diisopropyltryptamine in mice and rats. Pharmacol Biochem Behav 2006;83:122-9. [Crossref]
17. Van Hout MC, Hearne E. New psychoactive substances (NPS) on cryptomarket fora: An exploratory study of characteristics of forum activity between NPS buyers and vendors. Int J Drug Policy 2017;40:102-10. [Crossref]

18. Nonaka R, Nagi F, Ogata A, Satoh K. In vitro screening of psychoactive drugs by [35 S] GTP gamma S binding in rat. Biol Pharm Bull 2007;30:2328-33. [Crossref]

19. Johansson A, Lindstedt D, Roman M, Thelander G, Nielsen EI, Lennborn U et al. A non-fatal intoxication and seven deaths involving the dissociative drug 3-MeO-PCP. Forensic Sci Int 2017;275:76-82. [Crossref]

20. Fabregat-Safont D, Barneo-Muñoz M, Martinez-Garcia F, Sancho J V., Hernández F, Ibáñez M. Proposal of 5-methoxy-N-methyl-N-isopropyltryptamine consumption biomarkers through identification of in vivo metabolites from mice. J Chromatogr A 2017;1508:95-105. [Crossref]

21. Kilkenny C, Browne WJ, Cuthill IC, Emerson M, Altman DG. Improving bioscience research reporting: The ARRIVE guidelines for reporting animal research. PLoS Biol 2010; 29;8:e1000412 [Crossref]

22. Kamata T, Katagi M, Tsuchihashi H. Metabolism and toxicological analyses of hallucinogenic tryptamine analogues being abused in Japan. Forensic Toxicol 2010;28:1-8. [Crossref]

23. Herrera F, Martin V, Carrera P, Rodriguez-Blanco J, Rodriguez C, Antolín I. Tryptamine induces cell death with ultrastructural features of autophagy in neurons and glia: Possible relevance for neurodegenerative disorders. Anat Rec A Discov Mol Cell Evol Biol 2006;288:1026-30. [Crossref]

24. Noworyta-Sokołowska K, Kamińska K, Kreiner G, Rogóż Z, Gołembiowska K. Neurotoxic Effects of 5-MeO-DIPT: A Psychoactive Tryptamine Derivative in Rats. Neurotox Res 2016;30:606-19. [Crossref]

25. Elmore S. Apoptosis: A review of programmed cell death. Toxicol Pathol 2007;35:495-516 [Crossref]

26. Yang W, Guo C, Fan Hui, Liu F, Yin M. Studying the mRNA and protein expression pattern of apoptosis and autophagy-related genes in renal cell carcinoma. Int J Clin Exp Med 2017;10:14593-8.

27. Seif El-Din SH, El-Lakkany NM, Salem MB, Hammam OA, Saleh S, Botros SS Resveratrol mitigates hepatic injury in rats by regulating oxidative stress, nuclear factor-kappa B, and apoptosis. J Adb Pharm Technol Res 2016;7:99-104. [Crossref]

28. Lima da Cruz RV, Moulin TC, Petiz LL, Leão RN. A single dose of 5-MeO-DMT stimulates cell proliferation, neuronal survivability, morphological and functional changes in adult mice ventral dentate gyrus. Front Mol Neurosci 2018;11:312.doi: 10.3389/fnmol.2018.00312. eCollection 2018. [Crossref] 


\section{Supplementary file}

Shapiro Wilk test results are as shown in the table below.

\begin{tabular}{|c|c|c|c|c|c|c|c|}
\hline Caspase-3 & Shapiro-Wilk test & Control & Vehicle Control & $\begin{array}{l}0.27 \mathrm{mg} / \mathrm{kg} \\
5-\mathrm{MeO}-\mathrm{MiPT}\end{array}$ & $\begin{array}{l}2.7 \mathrm{mg} / \mathrm{kg} \\
5-\mathrm{MeO}-\mathrm{MiPT}\end{array}$ & Normal Q-Q Plot & \\
\hline \multirow[t]{3}{*}{ Liver } & $\mathrm{W}$ & 1,000 & 0,9643 & 0,9868 & 0,9932 & $150-1$ & - cratrol \\
\hline & $\mathrm{p}$ value & $>0,9999$ & 0,6369 & 0,7804 & 0,8428 & 窢1000 & $\therefore 0.27$ makh 5-Mo-MPT \\
\hline & $\begin{array}{l}\text { Passed normality test } \\
\text { (alpha }=0.05) ?\end{array}$ & Yes & Yes & Yes & Yes & & \\
\hline \multirow[t]{3}{*}{ Kidney } & $\mathrm{W}$ & 0,9643 & 1,000 & 1,000 & 0,9932 & & : Cratde \\
\hline & $\mathrm{p}$ value & 0,6369 & $>0,9999$ & $>0,9999$ & 0,8428 & & 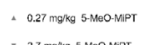 \\
\hline & $\begin{array}{l}\text { Passed normality test } \\
\text { (alpha }=0.05) ?\end{array}$ & Yes & Yes & Yes & Yes & & \\
\hline \multirow[t]{3}{*}{ Cerebrum } & $\mathrm{W}$ & 0,9231 & 0,9868 & 1,000 & 0,9423 & 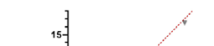 & $\begin{array}{l}\text { : Control } \\
\text { Vetide control }\end{array}$ \\
\hline & P value & 0,4633 & 0,7804 & $>0,9999$ & 0,5367 & $\frac{\square}{8} 10$ & $\therefore 027$ mokg s.Mmeamp \\
\hline & $\begin{array}{l}\text { Passed normality test } \\
(\text { alpha }=0.05) ?\end{array}$ & Yes & Yes & Yes & Yes & Actual & \\
\hline Caspase-8 & Shapiro-Wilk test & Control & Vehicle Control & $\begin{array}{l}0.27 \mathrm{mg} / \mathrm{kg} \\
5-\mathrm{MeO}-\mathrm{MiPT}\end{array}$ & $\begin{array}{l}2.7 \mathrm{mg} / \mathrm{kg} \\
5-\mathrm{MeO}-\mathrm{MiPT}\end{array}$ & Norma & \\
\hline \multirow[t]{3}{*}{ Liver } & W & 0,9643 & 0,9231 & 0,9868 & 0,9643 & $100=$ & : control \\
\hline & $\mathrm{p}$ value & 0,6369 & 0,4633 & 0,7804 & 0,6369 & & 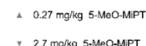 \\
\hline & $\begin{array}{l}\text { Passed normality test } \\
\text { (alpha }=0.05) ?\end{array}$ & Yes & Yes & Yes & Yes & & \\
\hline \multirow[t]{3}{*}{ Kidney } & $\mathrm{W}$ & 0,9231 & 0,9643 & 0,9643 & 1,000 & ${ }^{\circ 0}$ & :- Conted \\
\hline & $\mathrm{p}$ value & 0,4633 & 0,6369 & 0,6369 & $>0,9999$ & 然 & $\therefore$ 027 mang 5 \\
\hline & $\begin{array}{l}\text { Passed normality test } \\
\text { (alpha }=0.05) ?\end{array}$ & Yes & Yes & Yes & Yes & & \\
\hline \multirow[t]{3}{*}{ Cerebrum } & W & 1,000 & 1,000 & 1,000 & 0,8547 & ${ }^{30} 7$ & : Control \\
\hline & $\mathrm{p}$ value & $>0,9999$ & $>0,9999$ & $>0,9999$ & 0,2530 & $\frac{g^{\frac{2}{2}}}{20-}$ & . 027 mgkg 5HeOMPr \\
\hline & $\begin{array}{l}\text { Passed normality test } \\
(\text { alpha }=0.05) ?\end{array}$ & Yes & Yes & Yes & Yes & 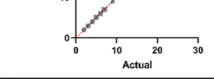 & \\
\hline
\end{tabular}

\begin{tabular}{|c|c|c|c|c|c|}
\hline & & \multirow{2}{*}{$\frac{\text { Caspase-3 }}{\text { Lower } 95 \% \text { CI of mean }}$} & \multicolumn{3}{|c|}{ Caspase- 8} \\
\hline & & & Upper $95 \%$ CI of mean & Lower $95 \%$ CI of mean & Upper $95 \%$ CI of mean \\
\hline \multirow[t]{4}{*}{ Liver } & Control & 5.232 & 8.101 & 0.7982 & 6.535 \\
\hline & Vehicle Control & 5.872 & 13.46 & 8.496 & 18.84 \\
\hline & $0.27 \mathrm{mg} / \mathrm{kg} 5-\mathrm{MeO}-\mathrm{MiPT}$ & 29.08 & 41.58 & 28.42 & 40.92 \\
\hline & $2.7 \mathrm{mg} / \mathrm{kg} 5-\mathrm{MeO}-\mathrm{MiPT}$ & 127.9 & 145.4 & 90.62 & 113.4 \\
\hline \multirow[t]{4}{*}{ Kidney } & Control & 1.539 & 9.128 & -1.504 & 8.838 \\
\hline & Vehicle Control & 13.55 & 28.45 & -1.922 & 13.26 \\
\hline & $0.27 \mathrm{mg} / \mathrm{kg} 5-\mathrm{MeO}-\mathrm{MiPT}$ & 11.06 & 30.94 & 7.465 & 13.20 \\
\hline & $2.7 \mathrm{mg} / \mathrm{kg} 5-\mathrm{MeO}-\mathrm{MiPT}$ & 67.61 & 85.06 & 35.58 & 60.42 \\
\hline \multirow[t]{4}{*}{ Cerebrum } & Control & 0.1622 & 10.50 & -1.303 & 7.303 \\
\hline & Vehicle Control & -0.9183 & 11.58 & 3.516 & 8.484 \\
\hline & $0.27 \mathrm{mg} / \mathrm{kg} 5-\mathrm{MeO}-\mathrm{MiPT}$ & 4.032 & 13.97 & 3.063 & 22.94 \\
\hline & $2.7 \mathrm{mg} / \mathrm{kg} 5-\mathrm{MeO}-\mathrm{MiPT}$ & 4.043 & 21.96 & 12.26 & 31.07 \\
\hline
\end{tabular}

